\title{
Assessing the Impact of Covid-19 Pandemic on Emerging Market Economies' (EMEs) Sovereign Bond Risk Premium and Fiscal Solvency
}

\author{
Menna Bizuneh ${ }^{1}$. Menelik Geremew ${ }^{2}$
}

Published online: 13 September 2021

(C) EEA 2021

\begin{abstract}
The current globalized economic environment has made Emerging Market Economies (EMEs) highly exposed to global economic shocks. During the Covid-19 pandemic, EMEs have been facing increased health costs and heightened demand for fiscal stimulus. In addition, most EMEs experienced currency depreciation, reversal in capital flow, decrease in global demand and significant decline in domestic revenue, leading to a potential increase in sovereign bond risk premiums (SRP). Using dynamic panel estimations and focusing on 12 countries, we find that the Covid-19 pandemic impacts SRP primarily through GDP growth and political stability indicators. In addition, we find the real exchange rate and net export to GDP ratio have a statistically significant impact on sovereign bond risk premium.
\end{abstract}

Keywords Covid-19 · Sovereign bond risk premium · EMEs · Fiscal Solvency

JEL F4 • E6 · H6

\section{Introduction}

The Covid-19 pandemic has had a global economic impact. The reduction in economic growth for many countries has come as a result of reduced labor supply, higher production cost, higher temporary inflation, and reduced social consumption (Wren-Lewis, 2020). The subsequent stringent lockdown measures implemented by many governments to protect susceptible populations has further amplified the

Menelik Geremew

menelik.geremew@kzoo.edu

Menna Bizuneh

Menna_Bizuneh@pitzer.edu

1 Department of Economics, Pitzer College, Claremont, CA 91711, US

2 Department of Economics and Business, Kalamazoo College, Kalamazoo, MI 49009, US 
contraction in economic activity. The reduction in economic activity has severely damaged government budgets throughout the world causing an increase in debt because of swelling budget deficit resulting from plummeting tax revenues and increasing expenditures.

Emerging Market Economies (EMEs) have not been immune to the increase in debt induced by the Covid-19 pandemic. However, pre-Covid-19 EMEs were already in debt distress and facing fragile access to international markets providing governments with limited fiscal space and capacity to react to external shocks. In the past few decades EMEs have increasingly turned to capital markets, both domestically and internationally, to meet their financing needs. Consequently, EME's increased borrowing has resulted in a significant increase in sovereign debt. In particular, sovereign debt in emerging markets has grown remarkably since the global financial crisis where there was a large cumulative inflow of foreign capital into the debt markets ${ }^{1}$.

Against this background and heightened uncertainty about the future vis-à-vis the end of the Covid-19 pandemic and its economic consequences, EMEs are facing economic challenges both in the short-and long-term. Many EMEs face both demand and supply side shocks resulting in depreciated currency against major currencies, reversal in capital flows and potential impacts to their current accounts. As such sovereign debt securities become a key method of funding. However, the economic fallout of the pandemic has made EMEs experience a 'sudden stop' of private capital flows at the onset of the pandemic in March 2020 (Buchheit and Gulati, 2021) and EME governments face higher bonds risk premiums associated with higher possibility of default due to more volatile capital flows (Tran, 2018).

Although several studies have analyzed the impact of the Covid-19 pandemic on sovereign debt risk premium, none of the prior literature to our knowledge discusses the impact of the pandemic on sovereign bond risk for EMEs. Our study attempts to fill this gap in the literature by shedding light on the channels and transmission mechanism through which the Covid-19 pandemic prompted negative economic shocks on EMEs through raising their sovereign bond risk premium and increasing the probability of fiscal insolvency.

The pandemic has affected all economies including advanced economies and developing economies in addition to EMEs. With regard to the sovereign bond risk premium of advanced economies, we do not see significant change in their sovereign risk premium ${ }^{2}$

\footnotetext{
1 It is worth noting that a large share of the inflow of capital was invested in local currency denominated bonds, which is a break from previous trends of foreign investors participating in foreign exchange denominated debt (Agur, Chan, Goswami and Sharma, 2019). This increased participation in local currency denominated bonds, albeit still a smaller share than the foreign currency denominated debt, helps many countries avoid what Eichengreen and Hausman (1999) termed as "original sin". "Original sin" refers to the fact that many countries do not borrow in their own currency at long maturities and fixed rates even in their home market. This will cause countries to experience currency mismatches or maturity mismatches resulting in financial fragility.

${ }^{2}$ G7 countries' risk premium is measured as the difference between each country's 30-year sovereign bond yield and the yield on an equivalent maturing US Treasury bond.
} 
as can be seen in Figure $3 b^{3}$. We found that the Year-on-Year percent (YoY\%) change in the measurement of sovereign bond risk premium for advanced economies, represented by the G7 countries had a practically flat line in the first three quarters of 2020. The lack of impact of Covid-19 on sovereign bond risk premiums is even more apparent when compared to the risk premium YoY\% change of EMEs in Figure 3a. Almost all EMEs in our sample experienced a spike in their risk premium in the first quarter of 2020. On the other hand, developing countries could face similar fiscal challenges as EMEs to mitigate the impact of Covid-19 on their economies. However, the lack of more frequent data and unavailability of macroeconomic data makes analyzing the impact of Covid-19 on sovereign bond premium for developing countries in a meaningful way difficult. The aforementioned details provide us with a strong motivation to concentrate our analysis on the effects of Covid-19 on EMEs' sovereign risk premium.

In addition, we focus this study on EMEs for three reasons. First, different from other groups, EMEs have less access to domestic currency denominated borrowing making them more vulnerable to sudden stops in credit. Second EMEs are at a younger stage of financial development which could result in a different mechanism through which sovereign debt impacts the real economy (Bernardini and Forni 2017). Finally, EMEs have limited capacity to effectively deploy monetary and fiscal policies in times of crisis. In EMEs both fiscal and monetary policies tend to be procyclical or acyclical. This feature of these policies denies EMEs of important macroeconomic stabilization tools (Coulibaly, 2012).

This paper adds to two branches of the literature. First, this study contributes to the vast literature that exists on the factors that influence sovereign bond risk premium in the context of EMEs ${ }^{4}$. Some analysis focus on country-specific fundamental as indicators of external financing (Hartelius, Kashiwase, and Kodres, 2008; Luengnaruemitchai and Schindler, 2007). Other studies examine the role countryspecific fundamentals such as debt and fiscal variables, reserves, GDP growth, and interest rates of various maturities play in explaining sovereign bond spreads (Baldacci, Gupta, and Mati 2009; Comelli, 2012; Eichengreen and Mody 1998; Kamin and Von Kleist 1999]. In addition, some studies highlight the importance of external global factors in accounting for spread dynamics (Kamin and Von Kleist, 1999; McGuire and Schrijvers, 2003; Uribe and Yue, 2006). There are also studies that focus on sovereign bond risk in general (Andries et al., 2020; Ferrucci, 2003; McGuire and Schrijvers, 2003). We contribute to this literature through the analysis

\footnotetext{
3 The risk premium for Italy however is an exception. The economic downturn was particularly strong in Italy, the most affected country in Europe by Covid-19, where the interest rate spread vis-à-vis Germany rose sharply from $1.4 \%$ to $2.5 \%$ and the stock market fell by $40 \%$ between February 19 and March 12 . However, there was a weak spillover effects from Italy to other European economies. It is also worth noting that the first confirmed Covid-19 cases (in France and shortly after in Italy) are the origin of an explosive increase in interest rate spreads on sovereign debt in the Eurozone. This explosive dynamic broke around the time of the ECB's intervention on March 12 and that otherwise, there could have been a sudden surge in rates in the countries most affected by Covid-19 (Italy, Spain, and France), possibly reaching spread values close to those observed during the 2010-2012 sovereign debt crisis in Europe within just a few days (Ortmans, and Tripier, 2021).

${ }^{4}$ Sovereign bond yield spreads capture the risk premium that governments have to pay on their debts. We will be using sovereign bond yield spreads interchangeably with sovereign bond risk premiums.
} 
of the impact of a significant economic shock associated with a pandemic on sovereign bond risk premium in EMEs.

Second, our work broadly relates to the fast-growing research that studies the economic implication of the Covid-19 outbreak and the subsequent economic shutdown policies and 'de-globalization' process, broadly termed as "Coronanomics" (Eichengreen, 2020) ${ }^{5}$. We add the impact of the pandemic on sovereign bond risk premiums to the current literature which examines the impact of Covid-19 on economic growth (Gormsen and Koijen, 2020), production (Biron and Zhu, 2020; Leijen, 2020), the supply-demand doom loop (Fornaro and Wolf, 2020), supply chain (Baldwin and di Maurao, 2020; Wong, Lin and Jackson, 2020; Luo and Tsang, 2020; Goel et al., 2021), financial markets (Haddad, Moreira, and Muir, 2020), capital flows (Ribakova, Hilgenstock, and Fortun, 2020), exchange rates and financial stability/ risk (Beck, 2020; Cecchetti and Schoenholtz, 2020; Cochrane, 2020), as well as debt crisis. There are a few papers that share our focus on the impact of Covid-19 specifically on EMEs (see Arellano, Bai, and Mihalache, 2020; Hevia and Neumeyer, 2020). However, to the best of our knowledge this paper is the first to focus on the impact of Covid-19 on emerging market economies' sovereign bond spread.

Focusing on 12 countries in four regions, our results show that the impact of the Covid-19 pandemic on sovereign bond risk premium comes through primarily macroeconomic channels such as GDP growth and external account indicators. In addition, EMEs with higher fiscal deficit to GDP ratio also experience higher sovereign risk premiums during Covid-19. Moreover, we find that political stability indicators and the great financial crisis of 2008-2009 have a statistically significant impact on sovereign bond risk premium.

The rest of the paper is organized as follows. The next section presents a brief description of economic impact of Covid-19 on EMEs. See section 'Data and Methodology' describes the data and the methodology utilized and see section 'Results' provides empirical analysis. We conclude with final remarks in see section 'Conclusion'

\section{Economic Trends in EME's During the Covid-19 Pandemic}

Since the first reported case on December 31, 2019 in Wuhan China, the Covid-19 has become a global pandemic with current case number of 110.3 million and 2.44 million death worldwide ${ }^{6}$. While the multiple waves of this virus were most severe in China (at the beginning of 2020), Europe, and the United States, EMEs also saw significant increase in case numbers and deaths. However, not all EME countries experienced a high surge in Covid-19 cased and related deaths. As can be seen in Figures 1 and 2, Brazil experienced a surge in Covid-19 cases and related deaths,

\footnotetext{
${ }^{5}$ In addition to dire health consequences, the Covid-19 outbreak has forced countries to lock-down borders, preventing normal flow of goods, capital and humans. Further, domestic business and production had to shut down at least temporarily.

6 Johns Hopkins, Coronavirus Research Center [Feb 18, 2021] https://coronavirus.jhu.edu/map.html.
} 


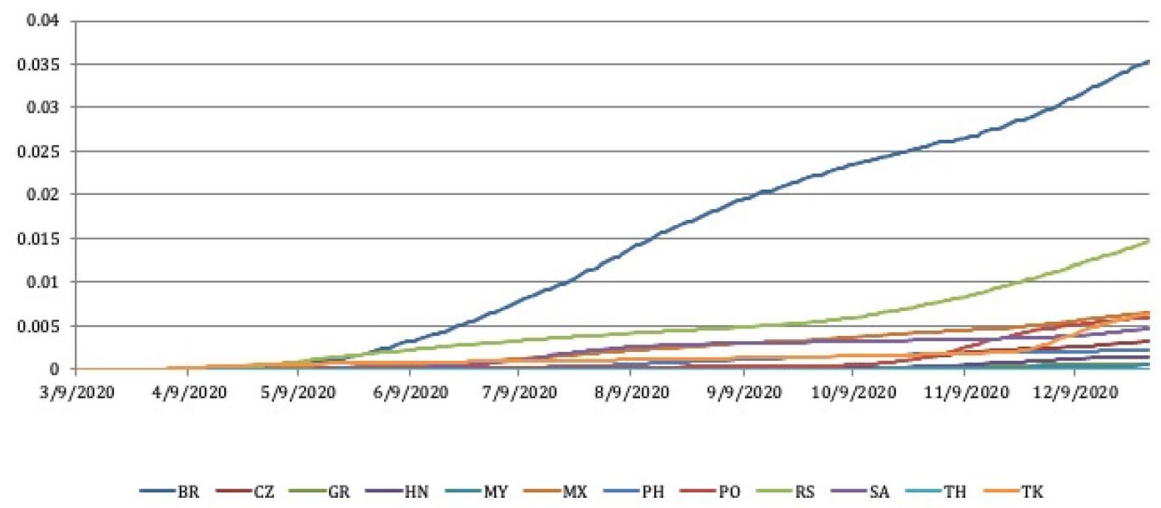

Fig. 1 Total daily COVID-19 cases per million-All EMEs (March 9-Dec. 29, 2020). Source: Data Stream, Reuters, Eikon. Notes: Figure shows total daily Covid cases per million people for the 12 countries in our panel. There is variation in the number of reported cases across countries at a given point in time and the growth rate over the nine-month period. Brazil experienced the fastest growth in the number of cases reaching to a high of 0.035 per million people by the end of year 2020, followed by Russia, Mexico and Poland

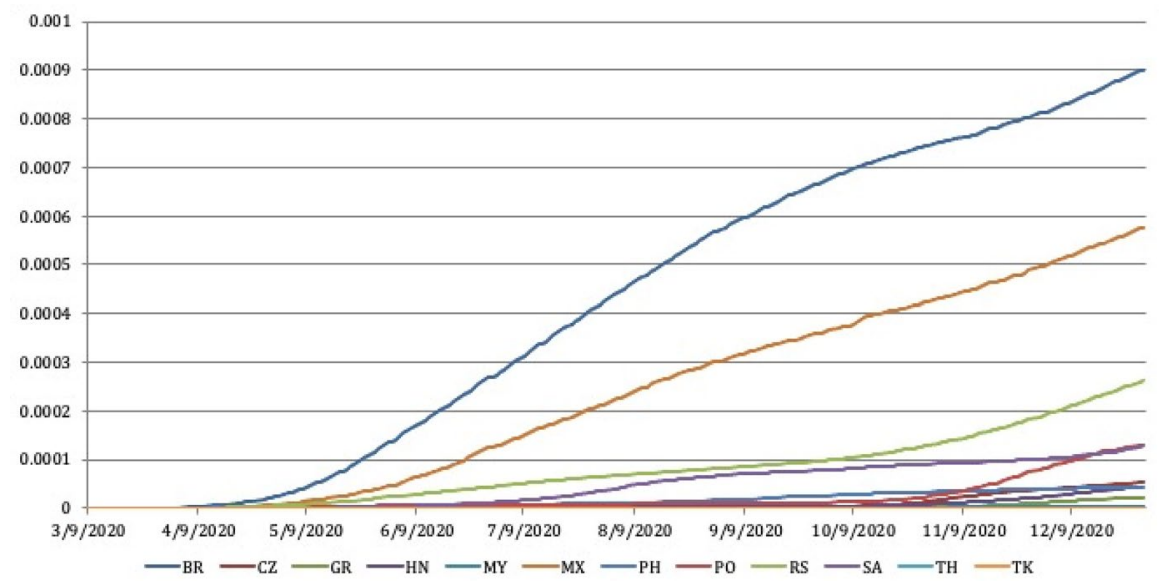

Fig. 2 Total daily COVID-19 related deaths per million- All EMEs (March 9- Dec. 29, 2020). Source: Data Stream, Reuters, Eikon. Notes: Figure shows total daily Covid-19 deaths per million people for the 12 countries in our panel. The fastest growth in deaths due to Covid-19 occurred during the summer of 2020. Countries that registered the highest number of cases is in figure 1, obviously show the fastest growth in the number of Covid-19 related deaths in Figure. Typically, Brazil, Mexico and Russia have been most affected by Covid-19 related deaths

while Philippines has much lower cases and death numbers. A country such as Russia experienced a surge in Covid-19 cases but the increase in cases did not translate into as many deaths.

In response to the Covid-19 pandemic many countries instituted a shelter-in-place and stay-at-home policies, which asks citizens not to go to work, not go to school, 
a

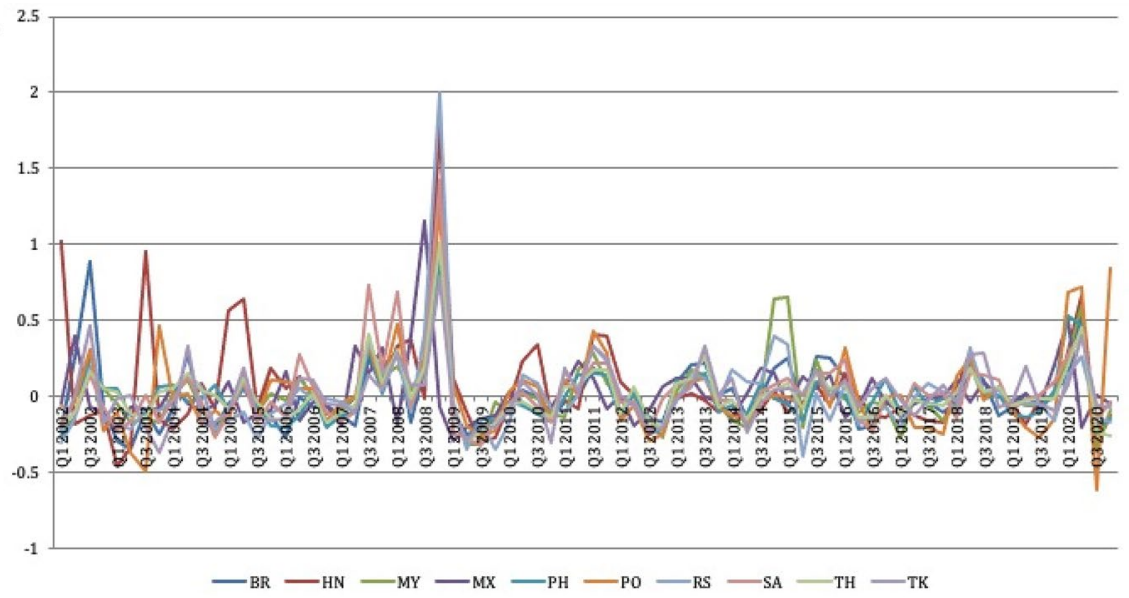

b

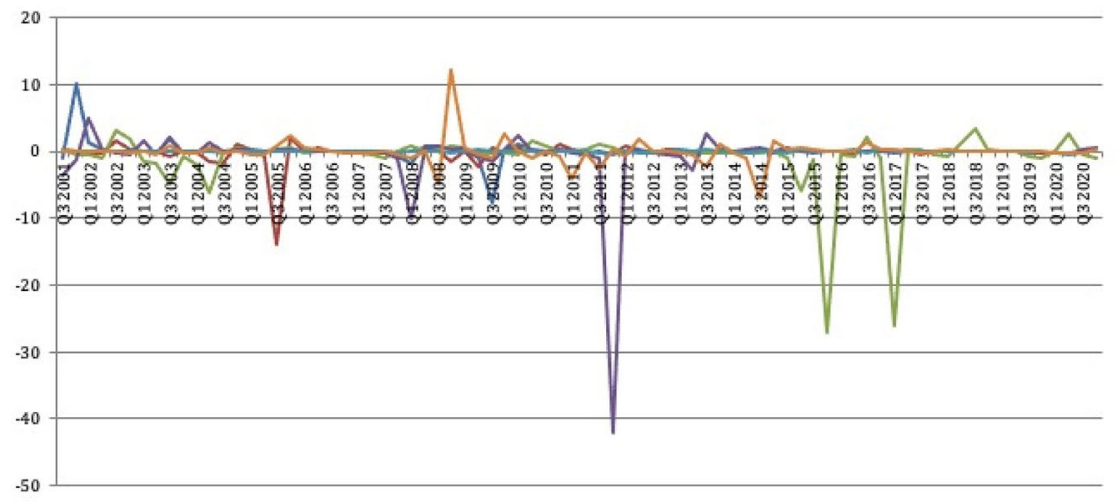

-Germany - Canada - Italy -France -Japan - Uk

Fig. 3 a YoY\% Change in USD Denominated Sovereign Debt Risk Premium-Selected EMEs (Q1:2002Q4:2020). Source: Data Stream, Reuters, Eikon. Notes: Figure a displays the YoY \% change in USDdenominated risk premium for 10 out 12 countries in our sample. Czech Republic and Greece are excluded because the data shows little variation and large outliers, respectively. EMEs experienced the biggest spike in their sovereign risk premium during the Great Financial Crisis (GFC). Post the GFC, EMEs experienced the largest increase in their risk premium during the Covid-19 pandemic. On a YoY basis for most countries in our sample, the risk premium increased by more than $50 \%$ during the first quarter of 2020. b YoY\% Change in USD Denominated Sovereign Debt Risk Premium- G7 Countries (Q3:2001-Q4:2020). Source: Data Stream, Reuters, Eikon. Notes: Figure b displays the YoY \% change in USD-denominated risk premium for G7 countries. These advanced economies did not see much change in their sovereign risk premium during the Covid-19 pandemic with the exception of Italy, which experienced $2.6 \%$ increase in their sovereign bond risk premium 
not leave the house at all, unless they have to ${ }^{7}$. Such policies in effect shut down many economic activities, especially in the service sector and created many delays. The direct impact of Covid-19 as well as the indirect impacts of the policies associated with it are heterogeneous in the perceived risk among EMEs. As can be seen from Fig. 3a, overall, at the start of the pandemic all countries in our panel experienced sharp increases in their risk premium. However, the difference in the increase in the risk premium, on a year-over-year (YoY) basis, ranges up to 50 basis points between countries such as Poland and Mexico.

Figure 4a shows external account indicators. We see that most currencies remained stable during the first six months of the pandemic. But between September and June most countries experienced currency depreciation. Most significantly, Russia, Turkey, Brazil \& India had depreciations in their real effective exchange rates ranging between 6 and 12\%. With regard to capital flows, Fig. 4b shows the biggest reversal in capital flow for EMEs occurred in the first quarter of 2020. A total outflow of more than $\$ 40 \mathrm{~B}$ in bonds and $\$ 5 \mathrm{~B}$ in equities occurred in the first quarter (Q1). The reversal in equities continued in the second (Q2) and third (Q3) quarters at a slower pace. With the flattening of the curve in Europe and other parts of the world by mid to late summer, the risk sentiment eased off and the net flows for bonds in Q2 and Q3 turned positive. ${ }^{8}$

Trends in macroeconomic indicators are presented in Fig. 5a, b, where a rising unemployment rate and severe GDP contraction, respectively can be observed for the year 2020. For example, Brazil experienced more than two percentage point increase in the unemployment rate, while for most other EMEs the unemployment rate increased by 0.5 to 1 percentage points, on a YoY basis. By the third quarter of 2020 all EMEs in our panel experienced negative growth in their GDP. Except for Poland, this negative growth has continued for all other countries in the fourth quarter of 2020. Emerging economies, which are already facing collapsing exports, decrease in remittances, government revenue loss must additionally face the impossible task of raising money where "original sin" has already made sovereign borrowing difficult. Furthermore, with commodity prices falling, decrease in foreign reserves and contracting GDP, it makes it difficult for policy makers to present an attractive case for borrowing to protect their societies from direct and indirect effects of the pandemic. In the next section, we explore more rigorously the relationship between the Covid-19 pandemic and the various mechanisms through which it affects sovereign bond spreads.

\footnotetext{
7 Most stay-in-shelter orders detail that violating the mandate is a misdemeanor punishable by fine, imprisonment or both. Some countries such as Spain, for example, had mandatory 6 weeks home confinement during the first wave of the pandemic while during the second wave they instituted curfews.

8 October 2020, World Economic Outlook Report
} 
a Currency Depreciation

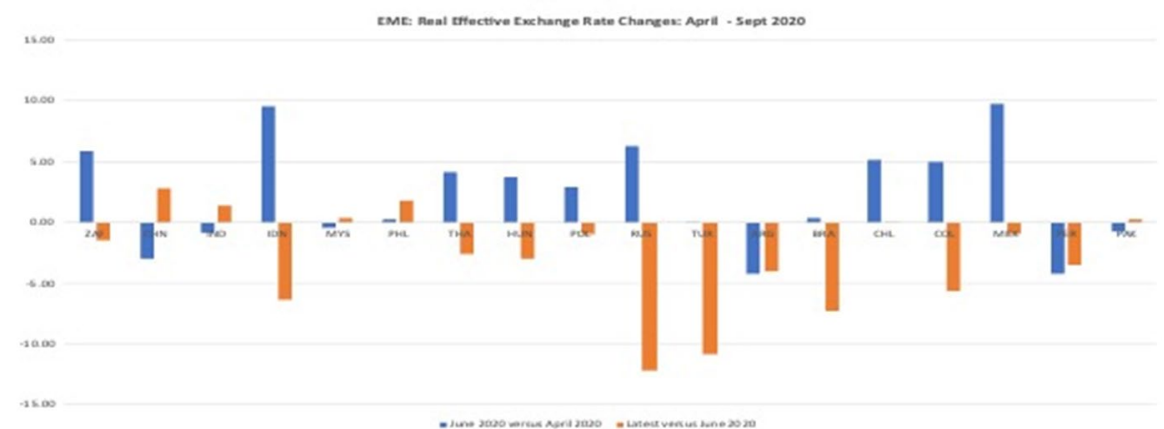

b Net Flows in Emerging Market Funds (Billions of US dollars)

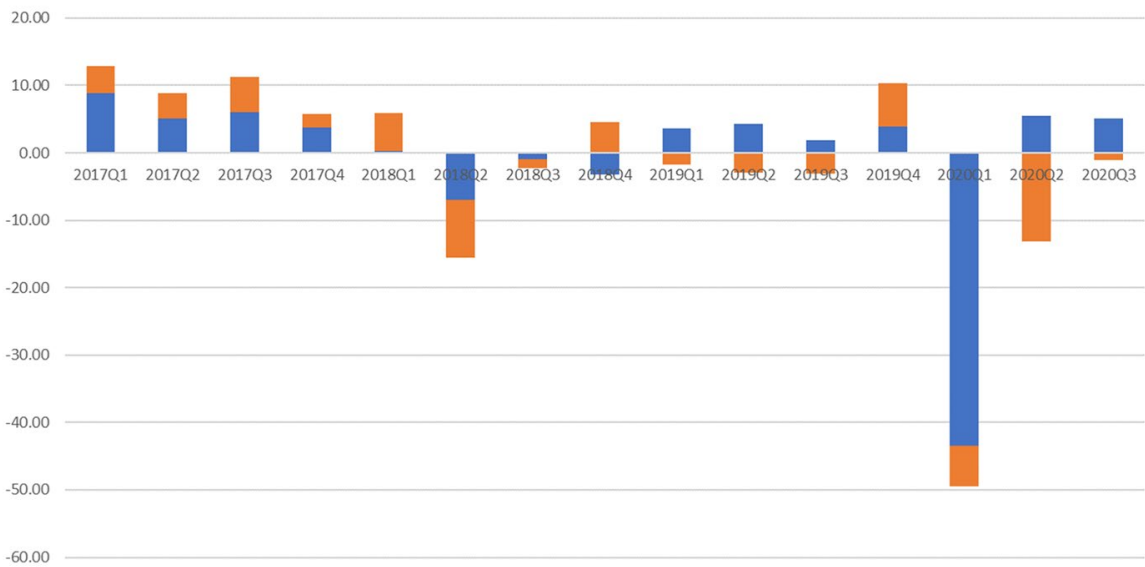

Bond = Equity

Fig. 4 a External Balance Indicators for EME Countries: Currency Depreciation. Source: World Economic Outlook, October 2020. Notes: Figure shows currency depreciation for countries classified as EMEs by the IMF. It compares currency depreciation between June vs. April 2020 (blue line) and October and June 2020 (orange line). Most EMEs experienced a depreciation rate in their currency of more than 5\% between June and October 2020, magnifying the impact of the Covid-19 pandemic on the economy of these countries. b External Balance Indicators for EME Countries: Net Capital Flows. Source: World Economic Outlook, October 2020. Notes: Figure 4b shows net flows in bonds (blue line) and equities (orange line) for countries classified as EMEs by the IMF. The biggest outflow of bonds and equities since 2017 for EMEs occurred during the first and second quarter of 2020. In total, there was an outflow of more than $\$ 40$ billion in bonds and $\$ 15$ billion in equities in the first two quarters of 2020

\section{Data and Methodology}

\section{Data}

To assess the impact of Covid-19 on sovereign bond risk premium, we use quarterly panel data on twelve EMEs from 2001Q1-2020Q4. The countries to be included in 


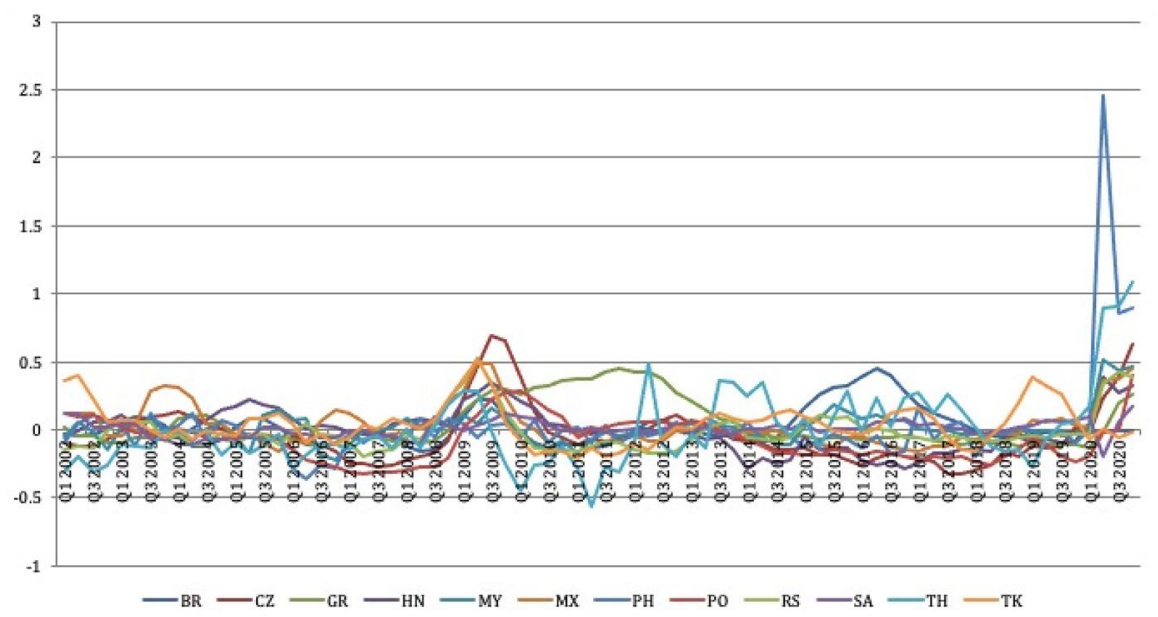

a

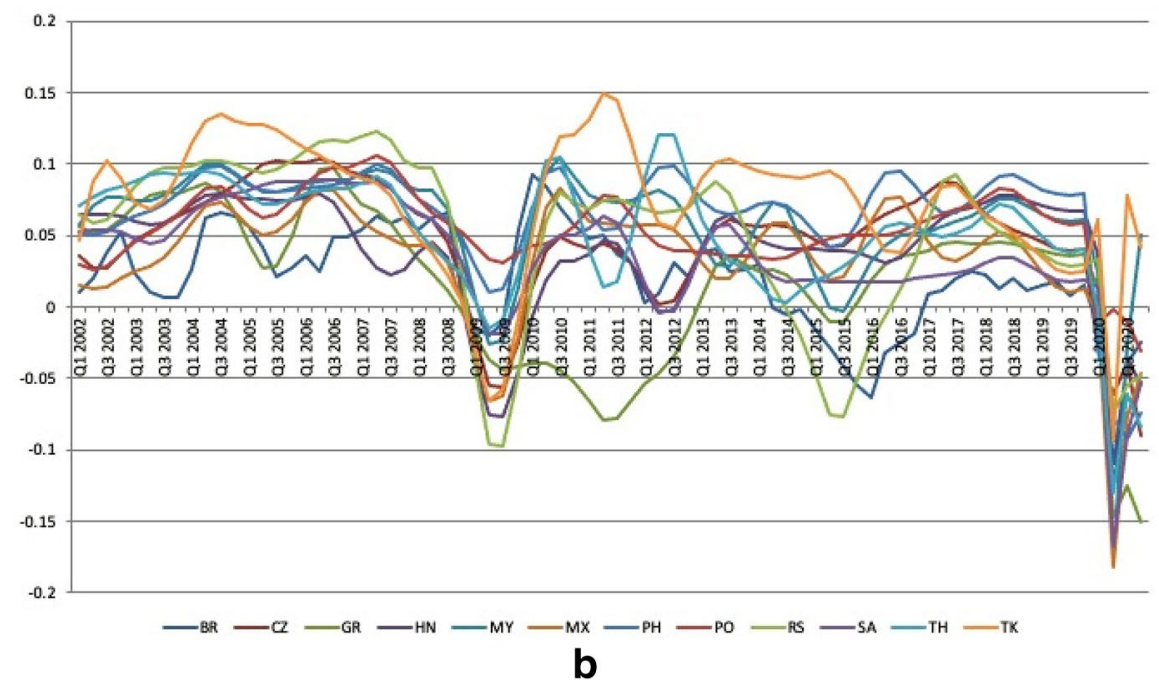

Fig. 5 a Macroeconomic Indicators for EME countries- YoY \% Change in the Unemployment for all EMEs (Q1:2002- Q4:2020). Source: Data Stream, Reuters, Eikon. Notes: Figure a hows the YoY \% change in the unemployment rate for all EMEs in our panel. All countries, except Turkey experienced a spike in the unemployment rate in the year 2020. For most EMEs, this sharp increase in the unemployment rate in the year 2020 is the highest by historical standards, even when compared with the GFC. b Macroeconomic Indicators for EME countries- YoY \% Change in the Real GDP for all EMEs (Q1:2002Q4:2020). Source: Data Stream, Reuters, Eikon. Notes: Figure b shows the YoY \% change in real GDP for the 12 EMEs in our panel. The figure clearly displays the biggest contraction in EME's economies since the year 2002. For most countries, real GDP declined by more than $10 \%$ on a YoY basis. In comparison with the GFC, the contraction in real GDP due to the Covid-19 pandemic is at least $5 \%$ more for most countries 
this study were selected based on two conditions. First the EMEs that were chosen to be studied were determined based on the classification of EMEs into this category by at least 5 out of 9 various organizations, who use different classification as see in the appendix Table 4. Second, we looked at only those emerging economies which have available data on our two risk premium measures the sovereign bond spread, $R P R$, and the economic and political risk evaluator, Sovereign Risk EPRE Score. Based on these qualifications, we narrowed down the list of countries to be studied to 12 EMEs located in 4 regions around the world.

Our primary dependent variable, $R P R$, is measured as the difference in the yield between a 10-year US treasury bond and a comparable maturity EME sovereign bond ${ }^{9}$. An increase in the spread of $R P R$ indicates an increase in sovereign bond risk premium. According to Tkalec et al. (2014), the sovereign bond spread is the compensation to investors for default risk in case the realized welfare loss from default is higher than the expected loss in welfare. We also utilize a different measurement of risk premium, Sovereign Risk EPRE Score, as a dependent variable to account for sovereign risk premium. The EPRE Score assesses economic and geopolitical risks in various countries including sovereign default risk.

The key variable of interest, COVID-19, is a dummy variable that takes on the value of one for all quarters in the year 2020 where Covid-19 cases have been reported for each country and zero otherwise using data provided by Ritchie $(2020)^{10}$. We expect that COVID-19 will have a positive relationship with the dependent variable. The Covid-19 pandemic is both a supply and demand shock triggering significant economic contraction and resulting in higher sovereign debt default risk as EMEs try to find resources to cope with already contracting economies.

In addition to the variable of interest we include other explanatory variables that have been demonstrated through the literature to be determinants of sovereign bond risk premiums ${ }^{11}$. List of variables included as regressors, their definition and their expected relationship to sovereign risk premiums can be found in Table 1. We include macroeconomic indicators such as real GDP growth rate, GDPGrRate, and unemployment rate, $U R$. The literature has identified that most of the variations in the sovereign bond spread are explained by GDP growth (see Borensztein and Panizza, 2009; Maltritz and Molchanov, 2013; Sturzenegger, 2004). We expect the relationship between real GDP growth, GDPGrRate, and sovereign debt risk premium to be negative since more productivity could lead to higher tax revenue and higher probability of repayment resulting in lower risk premiums. On the other

\footnotetext{
9 As defined by Hilscher and Nosbusch (2010), sovereign risk premium is the difference between the interest rate on a sovereign bond and the interest rate on a risk-free U.S. Treasury bond of comparable maturity.

${ }^{10}$ Ritchie, Ortiz-Ospina, Beltekian, Mathieu, Hasell, Macdonald, Giattino, Appel, Rodés-Guirao, and Roser (2020) provide the data for Our World in Data using multiple underlying resources. The dataset publishes up-to-date data on confirmed cases, deaths, hospitalization, testing, vaccination and other variables of interest related to the Covid-19 pandemic.

11 We discuss the source and summary statistics of our variables in Table 5 while correlation between variables is provided in Table 6in the appendix.
} 


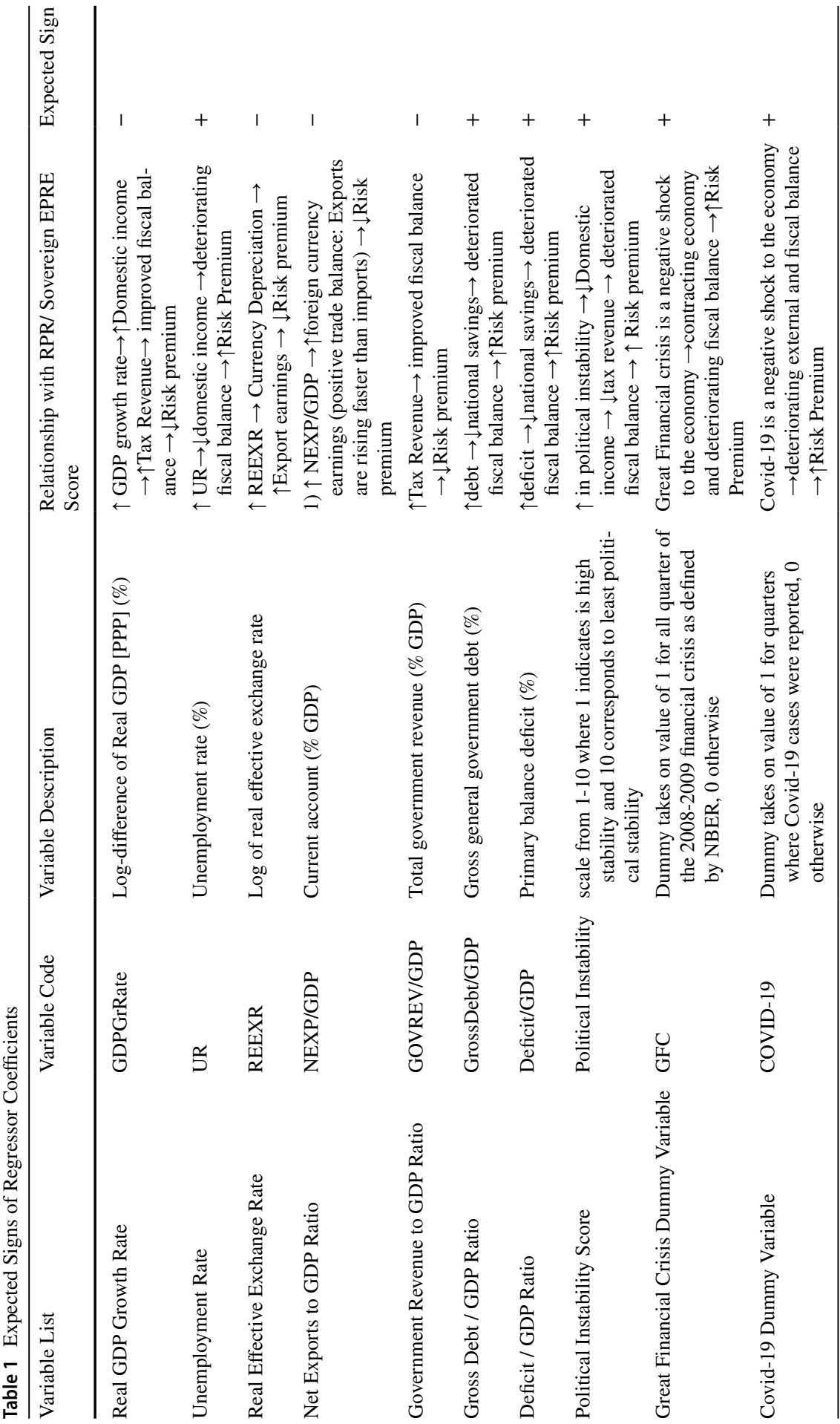


hand, we expect unemployment rate, $U R$, to have a positive relationship with government bond risk premium, as higher unemployment rate indicates worsening macroeconomic conditions and deteriorating fiscal balance (see Schmitt-Grohé and Uribe 2016; Shi, 2019).

We include a dummy variable for the Great Financial Crisis of 2008-2009, GFC, to account for period of another major global economic contractions ${ }^{12}$. Based on economic intuition, $G F C$ is expected to have a positive relationship with sovereign bond risk premium. The global financial crisis and its aftermath brought a decrease in economic growth for many countries resulting in higher sovereign risk bond premium. The effect of the Great Financial Crisis to EMEs was primarily passed through external shocks, however, countries' exposures to these shocks varied ${ }^{13}$. For Latin American countries, unlike previous crises, the financial channels were weaker, and countries had the opportunity to implement counter-cyclical monetary policies to fight the impact of the crises and subsequent recession. Instead, the trade channels were very strong and affected exporters through the reduction of world demand, especially demand from advanced economies (Ocampo, 2009). On the other hand, in Central and Eastern European (CEE) countries the crisis spread through equity, bond, foreign exchange and interbank markets, leading to a strong narrowing of external financing conditions (Mihaljek, 2010). As such, EMEs were not immune from the effects of the crisis in which they suffered declines in real GDP (see Didier et al., 2012; Aizenman et al., 2016) putting EME sovereigns at a higher risk of sovereign default leading to increased risk premium.

To account for fiscal conditions in each country prior to and during the Covid-19 pandemic we include variables related to government budgets, all as ratios of GDP. The variables include government revenue, Gov't Revenue/GDP, gross debt, Gross Debt/GDP and government deficit Deficit/GDP. An increase in tax revenue, Gov't Revenue/GDP, signals improved fiscal balances and is expected to have a negative relationship with sovereign debt risk premium supporting findings by studies such as Baldacci, Gupta, and Malti [2009]. On the flip side. the impact of fiscal deficits, Deficit/ GDP, and public debt, Gross debt/ GDP, are expected to have an adverse effect on sovereign bond risk premium by reducing national savings and leading to higher interest rates as shown by Kumar and Baldacci (2010) and De Grauwe and Ji (2012). Moreover, large deficits and debts, particularly if combined with uncertainties related to the pace of economic activity, could also raise concerns about the government's ability to service its debt and could result in raised credit risk premia (Blanchard, 1984; Elmendorf and Mankiw, 1999).

To control for external account indicators, we include countries' net exports as a ratio of GDP, NEXP/GDP, and the Real Effective Exchange Rate, REEXR. NEXP/ $G D P$, which is measured as the trade balance to GDP ratio is expected to have

\footnotetext{
12 The National Bureau of Economic Research's (NBER) Business Cycle Dating Committee maintains a chronology of business cycles in the United States. The record identifies the dates of peaks and troughs that frame economic expansions and recessions.

13 EMEs were not able to completely decouple, i.e. their business cycles become more (or fully) independent from advanced economies. Therefore, they were not able to completely avoid the impacts of the Great Financial Crisis.
} 
negative relationship with the risk premium. Improved competitiveness and trade surplus in the current account provide a positive signal to investors about a country's future repayment capacity and should reduce the sovereign bond risk premium. This finding is confirmed in the literature with studies such as Baldacci et al. (2009) and Maltritz and Molchanov (2013). The REEXR could affect the sovereign risk premium in two ways. On the one hand depreciation of the local currency could raise competitiveness of EMEs in the global commodities market leading to a reduction in the sovereign risk premium. On the other hand, if a country borrows in foreign currency rather than local currency ${ }^{14}$ then EMEs become less resilient to exchange rate swings in that a depreciation of the local currency would increase the value of the foreign currency debt (Hoffman et al., 2020) leading to an increase in the risk premium

Finally, to account for the political environment in each country we include the variable Political Instability Score that ranges in value between 1 and 10 where 10 indicates the least politically stable country whereas 1 goes in line with a highly stable country. As shown in Eichler (2014) we expect a country with better political environment to have a better country risk position in the global debt market, contributing to the reduction in the risk premium.

\section{Methodology}

Our modeling strategy follows Edwards (1985, 1986), and Tebaldi et al. (2018), where we assume the cost of financing a sovereign debt is the sum of the risk-free rate $\left(r_{f}\right)$ and a premium $(R P R)$ that quantifies the risk position of each specific country in the global debt market. Further, we assume that the risk premium is a function of the probability of default $\left(P_{d}\right)$ for the specific country, where a higher probability of default raises the risk premium and vice versa.

Assuming complete markets, risk neutral lenders, the equilibrium for a one period loan is given by

$$
\left(1-P_{d}\right) *\left[1+\left(r_{f}+R P R\right)\right]=\left(1+r_{f}\right)
$$

where $P_{d}$ is the probability of default, $r_{f}$ is the risk-free rate, and $R P R$ is the risk premium. After further simplification, the risk premium can be expressed as

$$
R P R=\left[\frac{P_{d}}{\left(1-P_{d}\right.}\right] *\left(1+r_{f}\right)
$$

\footnotetext{
${ }^{14}$ Post 1990s, most emerging economies focused their policy efforts in the reduction of foreign currency debt vulnerabilities, which resulted in a notable growth of local currency sovereign bond markets in many EMEs. The result of such efforts is to help overcame "original sin". Many EME sovereigns now routinely borrow in their local currency. However, due to small domestic investor base global investors are increasingly holding larger shares of EMEs' local-currency denominated bonds [Hofmann et al., 2020].
} 
Assuming a logistic distribution of the probability of default

$$
P_{d}=\frac{\left(\exp \sum \beta X\right)}{\left.1+\exp \sum \beta X\right)}
$$

and substituting in equation (2), we get:

$$
R P R_{i t}=\left(\exp \sum \beta_{i t} X_{i t}\right) *\left(1+r_{f i t}\right)
$$

Equation (4) forms the basis for our empirical model in this study. It shows the relationship between the risk premium on sovereign bond for country $i$ as a function of control variables $X_{\mathrm{i}}$ and the risk-free rate. Transforming Equation (4) using natural logs, results in:

$$
\ln R P R_{i, t}=\alpha_{i}+\sum \beta_{j, i, t} X_{j, i, t}+\varepsilon_{i, t}
$$

where $\ln R P R_{i, t}$ is the natural log of the sovereign risk premium for country $i$ at time $t$ is which is measured in two ways in our empirical model, i.e., (i) Difference between the yield on a 10-year-United States Treasury bond and an equivalent maturing United States dollar-denominated bond and (ii) Sovereign Risk Premium EPRE_Economic and Political Risk Evaluator Score. $\alpha_{i}$ is country fixed effect that also accounts for the risk-free rate, while $X_{j, i, t}$ is a vector of $j$ control variables for external accounts, government balance sheet, macroeconomic \& political stability indicators and dummies for Covid-19 and the great financial crisis (GFC) for country $i$ at time $t \beta_{j, i, t}$ are coefficients for $j$ variables, country $i$ at time $t$ and $\varepsilon_{i, t}$ are error terms.

To estimate the relationship between risk premium and our explanatory variables, we use a Dynamic Panel Model (DPM), which has become increasingly prevalent in many areas of study ${ }^{15}$. There are several advantages to utilizing DMP over Ordinary Least Squares (OLS) and other methods of estimation. First, DPM allows us to estimate the contemporaneous (short-run) and overall (long-run) relationships. DPM includes the lag of the dependent variable on the right-hand side of the regression equation which changes the interpretation of the right-hand side variables to contemporaneous correlations conditional on the history of the model, where the lag of the dependent variable contains the history of the model. Second, DPM allow estimating coefficients that are near time invariant by incorporating both within and between variations in the model. Finally, DPM uses Generalized Method of Moments (GMM) for estimation, which permits us to choose suitable instruments for the right-hand side variables which can then be tested for exogeneity with the error term.

We should note that estimating Equation (5) using a DPM involves two important econometric issues. First, the model potentially includes time invariant, unobservable country fixed effect characteristics (heterogeneity) and correlation between the

\footnotetext{
15 Some examples include Flannery and Hankins (2013) in corporate finance, Lee et al. (2012) in economic growth, Dutta et al. (2013) in foreign aid and Tebaldi et al. (2018) in international finance.
} 
Table 2 Impact of COVD-19 on risk premium for EMEs- RPR

\begin{tabular}{|c|c|c|c|}
\hline & \multicolumn{3}{|c|}{ Dependent Variable: RPR } \\
\hline & (1) & (2) & (3) \\
\hline $\mathrm{RPR}_{\mathrm{t}-1}$ & $\begin{array}{l}0.86 * * * \\
(0.014)\end{array}$ & $\begin{array}{l}0.866^{* * * *} \\
(0.014)\end{array}$ & $\begin{array}{l}0.861 \text { *** } \\
(0.014)\end{array}$ \\
\hline GDPGrRate & $\begin{array}{c}-21.259 * * * \\
(2.564)\end{array}$ & $\begin{array}{c}-20.203 * * * \\
(2.560)\end{array}$ & $\begin{array}{c}-21.172 * * * \\
(2.578)\end{array}$ \\
\hline UR & $\begin{array}{c}0.004 \\
(0.009)\end{array}$ & $\begin{array}{l}0.02 * * \\
(0.010)\end{array}$ & $\begin{array}{c}0.007 \\
(0.009)\end{array}$ \\
\hline NEXP/ GDP & $\begin{array}{r}-1.655 \\
(1.163)\end{array}$ & $\begin{array}{r}-0.568 \\
(1.180)\end{array}$ & $\begin{array}{r}-1.608 \\
(1.158)\end{array}$ \\
\hline REEX & $\begin{array}{r}-0.084 \\
(0.141)\end{array}$ & $\begin{array}{c}0.008 \\
(0.138)\end{array}$ & $\begin{array}{r}-0.054 \\
(0.137)\end{array}$ \\
\hline GOVREV / GDP & $\begin{array}{c}0.008 \\
(0.009)\end{array}$ & & \\
\hline GrossDebt/ GDP & & $\begin{array}{c}-0.008^{* * *} \\
(0.002)\end{array}$ & \\
\hline Deficit / GDP & & & $\begin{array}{c}0.002 \\
(0.006)\end{array}$ \\
\hline Political Instability & $\begin{array}{l}0.171 * * \\
(0.076)\end{array}$ & $\begin{array}{l}0.192 * * \\
(0.076)\end{array}$ & $\begin{array}{l}0.172 * * \\
(0.075)\end{array}$ \\
\hline GFC & $\begin{array}{r}-0.083 \\
(0.078)\end{array}$ & $\begin{array}{r}-0.090 \\
(0.077)\end{array}$ & $\begin{array}{r}-0.074 \\
(0.077)\end{array}$ \\
\hline COVID-19 & $\begin{array}{c}2.027 \\
(1.350)\end{array}$ & $\begin{array}{c}1.409 \\
(1.356)\end{array}$ & $\begin{array}{c}2.039 \\
(1.298)\end{array}$ \\
\hline COVID-19* GDPGrRate & $\begin{array}{l}16.184^{* * *} \\
(2.805)\end{array}$ & $\begin{array}{l}15.194 * * * \\
(2.793)\end{array}$ & $\begin{array}{l}15.889^{* * *} \\
(2.813)\end{array}$ \\
\hline COVId-19* UR & $\begin{array}{c}0.016 \\
(0.016)\end{array}$ & $\begin{array}{c}0.023 \\
(0.016)\end{array}$ & $\begin{array}{c}0.016 \\
(0.016)\end{array}$ \\
\hline COVID-19 * NEXP/GDP & $\begin{array}{c}7.032 \\
(6.517)\end{array}$ & $\begin{array}{c}3.495 \\
(6.564)\end{array}$ & $\begin{array}{c}9.204^{*} \\
(5.199)\end{array}$ \\
\hline COVID-19* REEXR & $\begin{array}{r}-0.504 \\
(0.322)\end{array}$ & $\begin{array}{r}-0.380 \\
(0.323)\end{array}$ & $\begin{array}{r}-0.533^{*} \\
(0.285)\end{array}$ \\
\hline COVID-19* GOVREV/ GDP & $\begin{array}{r}-0.005 \\
(0.012)\end{array}$ & & \\
\hline COVID-19* Gross Debt/GDP & -0.002 & $(0.012)$ & \\
\hline COVID-19 $*$ Deficit / GDP & & & $\begin{array}{c}0.007 \\
(0.020)\end{array}$ \\
\hline Constant & $\begin{array}{r}-0.002 * \\
(0.001)\end{array}$ & $\begin{array}{r}-0.001 \\
(0.001)\end{array}$ & $\begin{array}{r}-0.002 * \\
(0.001)\end{array}$ \\
\hline No. Obs. & 859 & 859 & 862 \\
\hline $\begin{array}{l}\text { Sargan test of overidentifying restrictions } \\
\quad\left[\mathrm{prb}>\chi^{2}\right]\end{array}$ & $1276.52[0.00]$ & $1263.2[0.00]$ & $1277.53[0.00]$ \\
\hline Test for AR(1) [prb > $\left.\chi^{2}\right]$ & $-4.858[0.00]$ & $-4.975[0.00]$ & $-4.833[0.00]$ \\
\hline Test for AR(2) [prb $\left.>\chi^{2}\right]$ & $-10.352[0.00]$ & $-10.424[0.00]$ & $-10.485[0.00]$ \\
\hline Wald test [prb $>\chi 2]$ & $6661.31[0.00]$ & $6686.43[0.00]$ & $6887.84[0.00]$ \\
\hline
\end{tabular}


Table 2 (continued)

Note: Standard Errors in parenthesis $* * *(* *, *)$ indicate statistical significance at the $1(5,10)$ percent level.

independent variables and the error term (endogeneity), which both could result in biased and inconsistent regression coefficients. Second, the inclusion of the lagged dependent variable on the right-hand side of the regression equation creates serial correlation in the errors. To overcome these problems, we follow Arellano and Bond (1991), Arellano and Bover (1995) and Blundell and Bond (1998) where we include global factors and time-specific effects as a constant in the model and use the GMM approach to obtain consistent estimates and eliminate heterogeneity as follows:

$$
\ln R P R_{i, t}=\alpha_{i}+\theta \ln R P R_{i t-1}+\sum_{j=1}^{j}\left(\beta_{j, i, t} X_{j, i, t}\right)+\varepsilon_{i, t}
$$

Equation (6) is a dynamic specification of Equation (5), where $\theta \ln R P R_{i t-1}$ is the one period lag of the dependent variable, and all other variables are as defined similarly as in Equation (5).

To obtain consistent estimates, we use the "difference GMM" which eliminates all the fixed effect terms and yields the following first-difference equation:

$$
\Delta \operatorname{lnRPR} R_{i, t}=\theta \Delta \ln R P R_{i, t-1}+\Delta \sum_{j=1}^{j}\left(\beta_{j, i, t} X_{j, i, t}\right)+\Delta \varepsilon_{i, t}
$$

where $\Delta \ln R P R_{i, t}$ is the risk premium and $\theta \Delta \ln R P R_{i, t-1}$ is the one period lag of the risk premium with coefficient $\theta . X_{j, i, t}$ is a list of explanatory variables including dummies for Covid-19 and the great financial crisis as well as interaction terms for country $i$ at time $t^{16}, \beta_{j, i, t}$ are the slope coefficients of the explanatory variables and $\varepsilon_{i, t}$ is the error term.

\section{Results}

We report estimated results of the dynamic panel models in Table $2{ }^{17}$, where the dependent variable $R P R$ measures the difference between the yield on a ten-year United States treasury bond and a comparable maturity EME sovereign bond. We start with a parsimonious model in the first column of Table 2 and add various control and interaction variables in the subsequent columns. The results show that a one-quarter lag of the dependent variable, $R P R_{t-1}$, is a positive and robust determinant of sovereign bond risk premium in Emerging Market Economies. Among the

\footnotetext{
16 Please see the list of the explanatory variables, their description and source in Table 6.

17 Along with the coefficient estimates, we also report the Sargan overidentifying restrictions test, the tests for first and second order autocorrelation of the residuals from equations in differences and the Wald test for joint significance of the repressors.
} 
Table 3 Impact of COVD-19 on risk premium for EMEs- Sovereign Risk EPRE Score

\begin{tabular}{|c|c|c|c|}
\hline & \multicolumn{3}{|c|}{ Dependent Variable: Sovereign Risk EPRE Score } \\
\hline & (1) & (2) & (3) \\
\hline Sovereign Risk EPRE Score ${ }_{t-1}$ & $\begin{array}{l}0.892 * * * \\
(0.012)\end{array}$ & $\begin{array}{l}0.892 * * * \\
(0.012)\end{array}$ & $\begin{array}{l}0.890 * * * \\
(0.012)\end{array}$ \\
\hline GDPGrRate & $\begin{array}{l}-2.38185^{* * *} \\
(0.548)\end{array}$ & $\begin{array}{c}-2.377 * * * \\
(0.549)\end{array}$ & $\begin{array}{l}-2.209^{* * *} \\
(0.547)\end{array}$ \\
\hline UR & $\begin{array}{c}-0.00206276 \\
(0.002)\end{array}$ & $\begin{array}{r}-0.002 \\
(0.002)\end{array}$ & $\begin{array}{r}-0.003 \\
(0.002)\end{array}$ \\
\hline NEXP/ GDP & $\begin{array}{c}-1.76295^{* * * *} \\
(0.261)\end{array}$ & $\begin{array}{c}-1.753^{* * *} \\
(0.265)\end{array}$ & $\begin{array}{l}-1.709 * * * \\
(0.256)\end{array}$ \\
\hline REEX & $\begin{array}{l}-0.0957031 * * * \\
(0.033)\end{array}$ & $\begin{array}{c}-0.095 * * * \\
(0.032)\end{array}$ & $\begin{array}{c}-0.095^{* * * *} \\
(0.032)\end{array}$ \\
\hline GOVREV / GDP & $\begin{array}{l}-0.000314592 \\
(0.002)\end{array}$ & & \\
\hline GrossDebt/GDP & & $\begin{array}{r}-0.0001 \\
(0.0005)\end{array}$ & \\
\hline Deficit / GDP & & & $\begin{array}{r}-0.002 * \\
(0.001)\end{array}$ \\
\hline Political Instability & $\begin{array}{c}-0.0151954 \\
(0.017)\end{array}$ & $\begin{array}{r}-0.015 \\
(0.017)\end{array}$ & $\begin{array}{r}-0.004 \\
(0.017)\end{array}$ \\
\hline GFC & $\begin{array}{l}0.0436322 * * \\
(0.017)\end{array}$ & $\begin{array}{l}0.043 * * \\
(0.017)\end{array}$ & $\begin{array}{l}0.045^{* * *} \\
(0.017)\end{array}$ \\
\hline COVID-19 & $\begin{array}{l}-0.558358^{* *} \\
(0.283)\end{array}$ & $\begin{array}{c}-0.564 * * \\
(0.285)\end{array}$ & $\begin{array}{r}-0.446 \\
(0.017)\end{array}$ \\
\hline COVID-19* GDPGrRate & $\begin{array}{l}2.29286^{* * * *} \\
(0.602)\end{array}$ & $\begin{array}{l}2.293^{* * * *} \\
(0.601)\end{array}$ & $\begin{array}{l}1.959^{* * * *} \\
(0.6)\end{array}$ \\
\hline COVId-19* UR & $\begin{array}{l}0.00336229 \\
(0.003)\end{array}$ & $\begin{array}{c}0.003 \\
(0.003)\end{array}$ & $\begin{array}{l}0.006 * * \\
(0.003)\end{array}$ \\
\hline COVID-19* NEXP/GDP & $\begin{array}{l}1.04846 \\
(1.200)\end{array}$ & $\begin{array}{c}1.000 \\
(1.221)\end{array}$ & $\begin{array}{c}1.128 \\
(1.031)\end{array}$ \\
\hline COVID-19* REEXR & $\begin{array}{l}0.125874 * \\
(0.065)\end{array}$ & $\begin{array}{c}0.127 * \\
(0.066)\end{array}$ & $\begin{array}{l}0.140 * * \\
(0.061)\end{array}$ \\
\hline COVID-19* GOVREV/ GDP & $\begin{array}{l}0.00326347 \\
(0.002)\end{array}$ & & \\
\hline COVID-19* Gross Debt /GDP & 0.003 & $(0.002)$ & \\
\hline COVID-19 $*$ Deficit / GDP & & & $\begin{array}{l}0.019 * * * \\
(0.004)\end{array}$ \\
\hline Constant & $\begin{array}{l}-0.00107076^{* * *} \\
(0.0002)\end{array}$ & $\begin{array}{c}-0.001 * * * \\
(0.0003)\end{array}$ & $\begin{array}{c}-0.001^{* * *} \\
(0.0003)\end{array}$ \\
\hline No. Obs. & 864 & 864 & 864 \\
\hline $\begin{array}{l}\text { Sargan test of overidentifying restrictions } \\
\quad\left[\mathrm{prb}>\chi^{2}\right]\end{array}$ & $822.475[0.7371]$ & $822.537[0.737]$ & $826.76[0.7014]$ \\
\hline Test for AR(1) [prb > $\left.\chi^{2}\right]$ & $-11.420[0.00]$ & $-11.415[0.00]$ & $-11.299[0.00]$ \\
\hline Test for AR(2) [prb > $\left.\chi^{2}\right]$ & $-0.586[0.558]$ & $-0.588[0.557]$ & $-0.719[0.472]$ \\
\hline Wald test $\left[\mathrm{prb}>\chi^{2}\right]$ & $9444.86[0.00]$ & $9445.98[0.00]$ & $9722.75[0.00]$ \\
\hline
\end{tabular}


Table 3 (continued)

Note: Standard Errors in parenthesis $* * *(* *, *)$ indicate statistical significance at the $1(5,10)$ percent level.

control variables, the results show that Real GDP Growth has a negative impact on sovereign bond risk premium and is statistically significant at $1 \%$ level across all specifications implying good performance in the economy provides confidence to investors in the global bond market and reduces the risk premium for EMEs. Unemployment rate, $U R$, also has a positive impact on $R P R$, however, the result is not robust. In terms of underlying political conditions, Political Instability Score is positive and statistically significant across all specifications indicating that greater political instability will result in higher sovereign bond risk premium for EMEs.

The control variable for the great financial crisis, $G F C$, has a negative coefficient contrary to expectation but is also found to have no statistical significance in terms of explaining the variation in risk premium for EMEs. Comparatively, our variable of interest, COVID-19, demonstrates a positive relationship between the pandemic and sovereign bond risk premium albeit not statistically significant. Even though the COVID-19 dummy on its own is not a statistically significant determinant of sovereign bond risk premium, the interaction terms of the COVID-19 dummy and the other control variables indicate that the impact of the pandemic on sovereign bond risk premium is mostly felt through the economic growth channel. When GDPGrRate is interacted with COVID-19 the result is a positive coefficient across the three models presented in Table 2 and statistically significant at $1 \%$ level. This positive relationship indicates that GDP growth rates experienced during the Covid-19 pandemic resulted in higher risk premium for EME governments. During the Covid-19 pandemic growth rates in all the EME countries in our sample were negative as can be seen from Figure 5b. In turn this significant decrease in GDP growth rate signaled to lenders a substantial decrease in economic activity which would make it difficult for EMEs to service their existing (and future) debts leading to higher sovereign bond risk premium.

We also see that the effect of REEXR during Covid-19 is negative albeit not robust as illustrated by the variable COVID-19*REEXR ${ }^{18}$. Neoclassical economic theory predicts that an increase in real effective exchange rate resulting in a depreciated currency should make EMEs have a higher dollar-denominated debt burden and lead to an increase in the sovereign debt risk premium. However, when REEXR is interacted with COVID-19 the result shows a negative relationship with $R P R$. This demonstrates how a positive trade balance, where exports are rising faster than imports, can lead to higher foreign currency earnings. Such earnings would place EMEs in better position to pay off their foreign currency denominated debt and lower risk premium.

As a robustness test, in Table 3, we utilize a different measurement of risk premium as the dependent variable, Sovereign Risk EPRE Score. The reason we

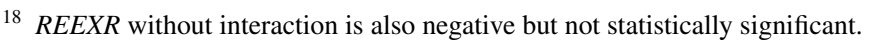


decided to use this measure of risk premium is because, (i) it is a composite measure of the sovereign risk position of countries ranking them 1-10 where 1 indicates the least risky and 10 is the riskiest. This categorical ranking allows grouping countries in their risk position and measure its response to our explanatory variables; (ii) This measure is constructed using information on yield on sovereign bond from the previous period, which allows us to capture the non-contemporaneous relationship between the risk premium and the explanatory variables. We introduce this dependent variable in the same three specifications as provided in Table 3, where we look at the impact of variables related to macroeconomics, external balances, political stability, the COVID-19 and the GFC dummy as well as the interaction terms on sovereign risk premium.

The estimation shows that GDP growth rate is negative and statistically significant across all specifications. The results further reaffirm the findings from the previous estimation that an interaction of the GDP growth rate with the COVID-19 will result in a statistically significant positive coefficient highlighting the impact of Covid-19 on GDP growth rate and in turn the sovereign risk premium. In a similar vein the unemployment rate measurement, $U R$, is negative and turns positive when interacted with the COVID-19 dummy. In both cases, the results associated with unemployment rate are not statistically robust. Vis-à-vis the political environment in EMEs, the variable Political Instability Score has a negative relationship with Sovereign EPRE Score but is not statistically significant across any of the three specifications.

The external account indicators, NEXP/GDP and REEX are statistically significant at $1 \%$ level and negative indicating the significant contribution of current account surplus and real exchange depreciation toward reduction in the risk premium. When these two variables are interacted with the COVID-19 dummy, however, the signs flip to positive and the REEXR is significant at $10 \%$ level and the $N E X P / G D P$ variable becomes statistically insignificant. We believe the change in sign is indicative of the heavy-handed negative impact of the Covid-19 pandemic on EMEs' risk premium through the external account channel similar to the impact of the growth rate of GDP.

The Covid-19 dummy is found to be statistically significant at $5 \%$ level in two out of the three models but has a negative sign. The unexpected sign can be explained though the fact that even though Covid-19 was announced as a pandemic by the World Health Organization (WHO) in the first quarter of 2020 and most advanced economies have reported cases and already started lockdown measures, most EMEs in our sample had their economies running at full capacity. We believe, especially in the first two quarters of 2020, investors might have looked at EMEs' sovereign bonds as attractive investment opportunities compared to advanced economies, potentially leading to a negative (decrease in magnitude) relationship with the risk premium.

Notably, the variable $G F C$ is positive and statistically significant at 5\% level. This result shows the clear divergence between the two recessions, one caused by financial crisis and another by a pandemic. The GFC was a financial crisis which hit the banking sector hard leading to contagion effects between advanced and emerging economies. Investors had to swiftly recalculate their risk and rebalance their 
portfolio especially in terms of their investments in sovereign bonds with governments that are highly indebted and exposed to the financial sector. A good example is the sovereign debt crisis in southern European countries such as Greece, where the great financial crisis resulted in sharp increase in sovereign bond risk premium. In contrast, the Covid-19 pandemic is not a financial crisis and in most cases banks were capitalized and liquid and there was little reason for investors to panic, at least in the initial periods of the pandemic. As explained above the impact of the Covid19 pandemic on the risk premium came into effect after EMEs' economies experienced sharp contractions.

The coefficients on fiscal condition measurements of GOVREV/GDP, Gross Debt/GDP and Deficit/GDP are all negative and but only Deficit/GDP has statistical significance. The numerical value of the data for Deficit/GDP ratio for most of the countries in our panel is negative, which makes the statistically significant negative coefficient meaningful and consistent with the theory. When interacted with COVID-19, the three variables related to government budget become positive, but only the interaction of the fiscal deficit with COVID-19 is statistically positive. This finding indicates that the governments' fiscal balances are one of the channels through which the pandemic has affected the sovereign risk premium. In particular, a one percentage point increase in Gross Debt/ GDP and Deficit/GDP during the pandemic will result in 0.003- and 0.19-point increase in the Sovereign Risk EPRE Score, respectively. Moreover, the positive coefficient associated with COVID$19 * G O V R E V / G D P$ illustrates that a decrease in government revenue associated with shrinking economies in most emerging market economies has increased the sovereign risk premium.

\section{Conclusion}

The global Covid-19 pandemic has been a severe shock (demand and supply side) to all economies. In particular, EMEs, who rely heavily on external borrowing, have found their hands tied when it comes to dealing with such economic shocks as well as other socio-economic issues due to the fact that their ability to borrow has decreased significantly. 
Overall, our results suggest that the impact of Covid-19 has manifested through the macroeconomic channels such as GDP growth rate, through external accounts channels, and fiscal environment indicators. As EMEs experience significant declines in their economic growth due to the loss in productivity caused by the pandemic and the subsequent policies put in place to reduce the spread of the virus, their ability to pay their debts as well as secure future loans has dwindled. Furthermore, this epidemic threatens to be not only a large health and economic crisis, but also a prolonged debt crisis. Moving forward, policies such as debt relief programs can have profound positive effects by supporting consumption, reducing the severity of debt crises, and saving lives.

Since the first reported case on December 31, 2019 in Wuhan, China, the COVID19 has become a global pandemic with current case number of 110.3 million and 2.44 million death worldwide ${ }^{19}$. While our study spotlights the impact of this global phenomenon on sovereign bond risk premiums in emerging market economies, the impact of the pandemic on debt repayment capacity has also been experienced in developing and other non-EME countries as well. Therefore, given better data availability for various countries for risk premiums, external accounts and macroeconomic indicators, future research can explore the potential impact of the Covid-19 pandemic on non-EME countries.

\section{Appendix}

See Tables 4, 5 and 6.

19 Johns Hopkins, Coronavirus Research Center (Feb 18, 2021) https://coronavirus.jhu.edu/map.html. 


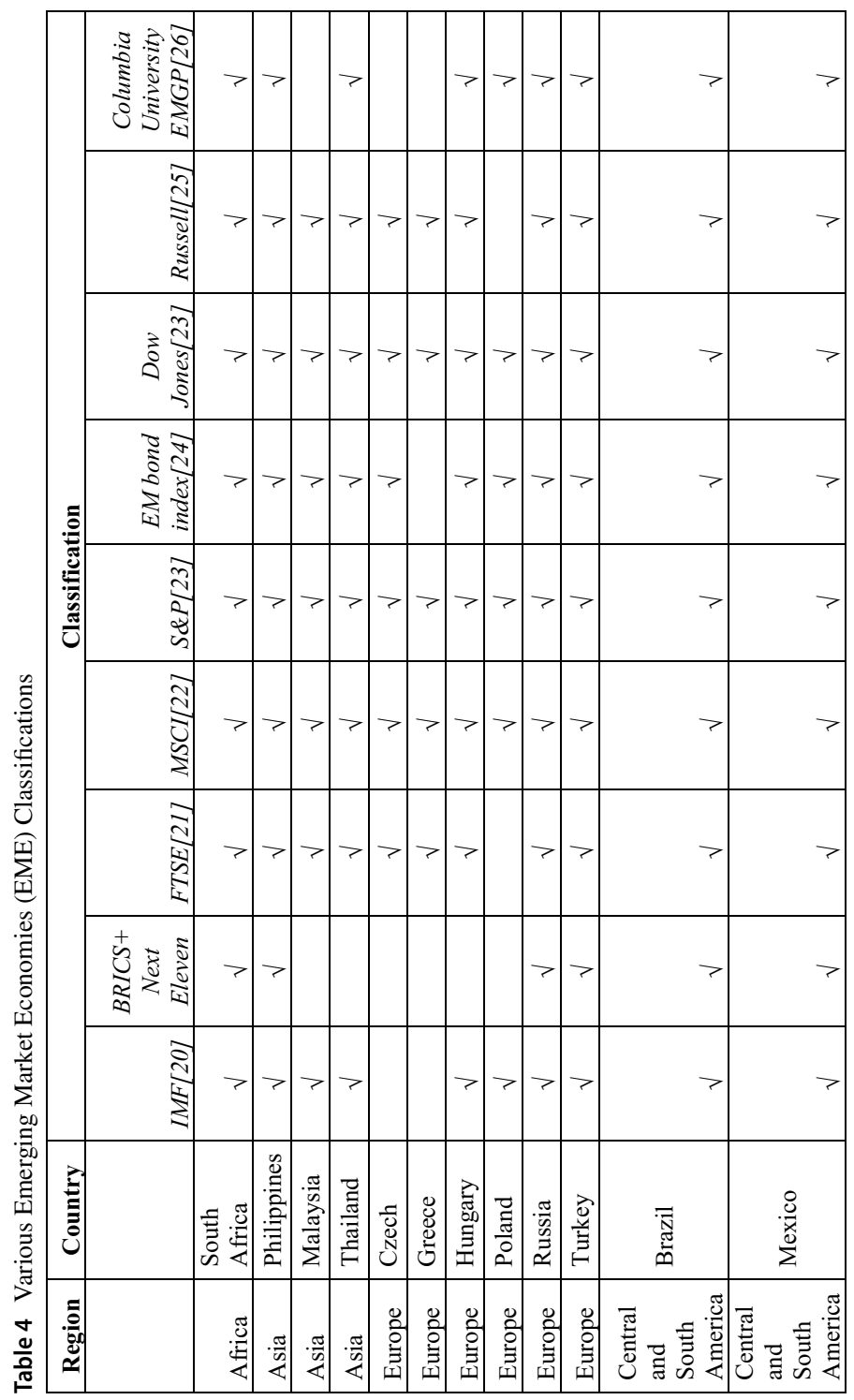

站。 
Table 5 Summary statistics

\begin{tabular}{|c|c|c|c|c|c|c|c|}
\hline Source & Variable & & Mean & Median & Std. Dev. & Min & $\operatorname{Max}$ \\
\hline $\begin{array}{l}\text { Data Stream, Reuters, } \\
\text { Eikon }\end{array}$ & RPR & $\begin{array}{l}\text { Overall } \\
\text { between } \\
\text { within }\end{array}$ & 2.36 & 1.95 & $\begin{array}{l}2.26 \\
1.11 \\
2.01\end{array}$ & -0.7 & 21.5 \\
\hline $\begin{array}{l}\text { Data Stream, Reuters, } \\
\text { Eikon }\end{array}$ & $\begin{array}{l}\text { Sovereign Risk EPRE } \\
\text { Score }\end{array}$ & $\begin{array}{l}\text { Overall } \\
\text { between } \\
\text { within }\end{array}$ & 4.49 & 4.4 & $\begin{array}{l}0.76 \\
0.59 \\
0.5\end{array}$ & 2.5 & 6.7 \\
\hline $\begin{array}{l}\text { Data Stream, Reuters, } \\
\text { Eikon }\end{array}$ & UR & $\begin{array}{l}\text { Overall } \\
\text { between } \\
\text { within }\end{array}$ & 8.9 & 7.27 & $\begin{array}{l}6.92 \\
6.5 \\
3.03\end{array}$ & 0.48 & 34.15 \\
\hline $\begin{array}{l}\text { Data Stream, Reuters, } \\
\text { Eikon }\end{array}$ & GDPGrRate & $\begin{array}{l}\text { Overall } \\
\text { between } \\
\text { within }\end{array}$ & 0.01 & 0.01 & $\begin{array}{l}0.02 \\
0.004 \\
0.02\end{array}$ & 0.21 & 0.18 \\
\hline $\begin{array}{l}\text { Data Stream, Reuters, } \\
\text { Eikon }\end{array}$ & NEXP/GDP & $\begin{array}{l}\text { Overall } \\
\text { between } \\
\text { within }\end{array}$ & -0.006 & -0.004 & $\begin{array}{l}0.03 \\
0.02 \\
0.02\end{array}$ & -0.18 & 0.09 \\
\hline $\begin{array}{l}\text { Data Stream, Reuters, } \\
\text { Eikon }\end{array}$ & REEXR & $\begin{array}{l}\text { Overall } \\
\text { between } \\
\text { within }\end{array}$ & 4.5 & 4.56 & $\begin{array}{l}0.21 \\
0.09 \\
0.19\end{array}$ & 3.16 & 5.55 \\
\hline $\begin{array}{l}\text { Data Stream, Reuters, } \\
\text { Eikon }\end{array}$ & GOVREV/GDP & $\begin{array}{l}\text { Overall } \\
\text { between } \\
\text { within }\end{array}$ & 28.07 & 25.21 & $\begin{array}{c}10.45 \\
10.6 \\
2.69\end{array}$ & 11.6 & 56.8 \\
\hline $\begin{array}{l}\text { Data Stream, Reuters, } \\
\text { Eikon }\end{array}$ & GrossDebt/GDP & $\begin{array}{l}\text { Overall } \\
\text { between } \\
\text { within }\end{array}$ & 52.44 & 45.76 & $\begin{array}{l}37.84 \\
36.39 \\
14.12\end{array}$ & 5.34 & 253.36 \\
\hline $\begin{array}{l}\text { Data Stream, Reuters, } \\
\text { Eikon }\end{array}$ & Deficit/GDP & $\begin{array}{l}\text { Overall } \\
\text { between } \\
\text { within }\end{array}$ & -1.28 & -1.19 & $\begin{array}{l}4.20 \\
1.79 \\
3.86\end{array}$ & -26.4 & 15.33 \\
\hline $\begin{array}{l}\text { DataStream, Reuters, } \\
\text { Eikon }\end{array}$ & Political Instability & $\begin{array}{l}\text { Overall } \\
\text { between } \\
\text { within }\end{array}$ & 4.92 & 4.9 & $\begin{array}{l}0.98 \\
0.98 \\
0.29\end{array}$ & 2.9 & 7.0 \\
\hline
\end{tabular}

https://www.thomsonreuters.com/content/dam/openweb/documents/pdf/tr-com-financial/fact-sheet/datas tream-economics-fact-sheet.pdf 


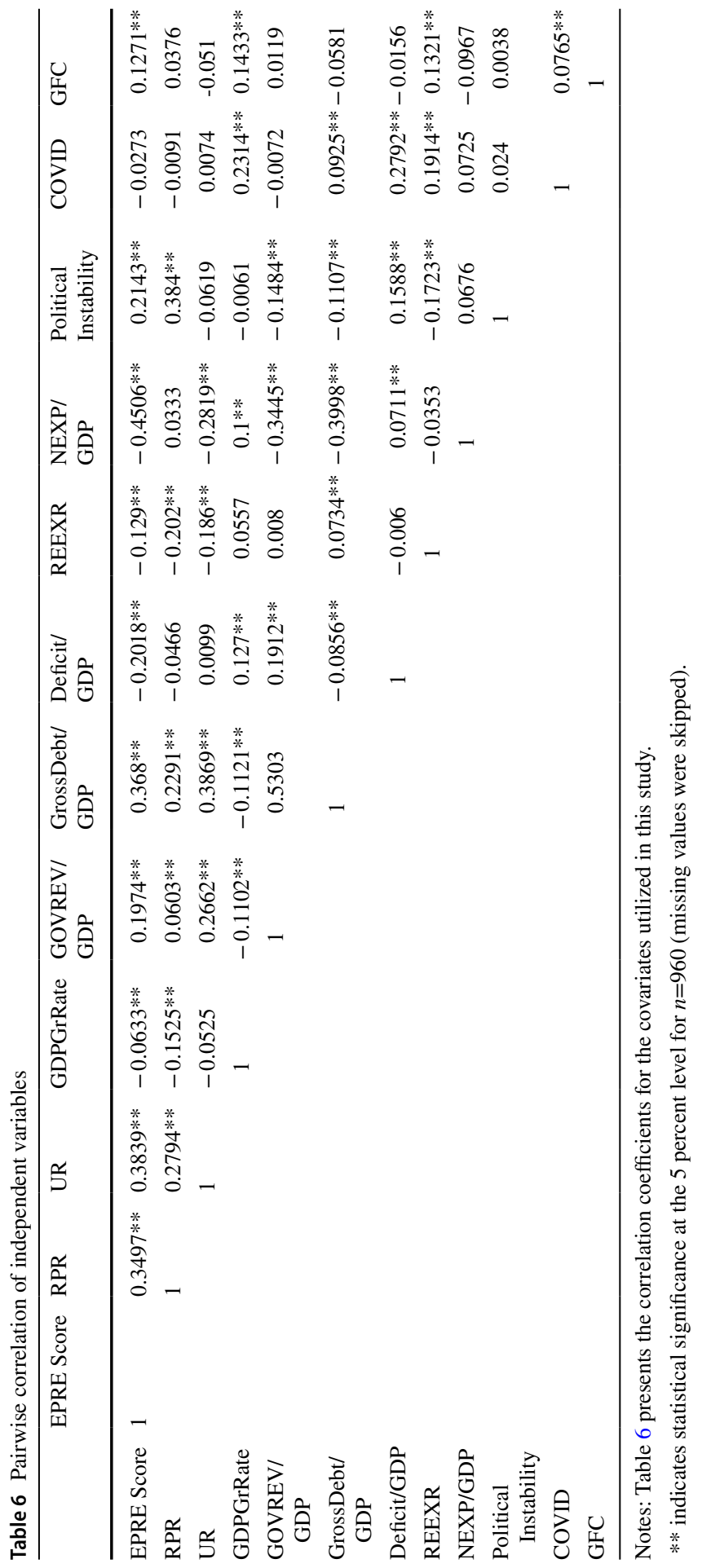

我这 
Acknowledgements We would like to thank the participants at the Southern, Eastern, Mid-West and Western Economic Association Conference participants for their valuable comments and suggestions. We also wish to thank Fabio Ghironi, two anonymous reviewers and Eastern Economic Journal editor Cynthia Bansak for their recommendations that has improved this paper.

\section{References}

Agur, Itai, Melissa Chan, Mangal Goswami, and Sunil Sharma. 2019. On International Integration of Emerging Sovereign Bond Markets. Emerging Markets Review 38: 347-363.

Aizenman, Joshua, Yothin Jinjarak, and Donghyun Park. 2016. Fundamentals and Sovereign Risk of Emerging Markets. Pacific Economic Review 21(2): 151-177.

Andries, Alin Marius, Steven Ongena, and Nicu Sprincean. 2020. The COVID-19 Pandemic and Sovereign Bond Risk. Swiss Finance Institute Research Paper 20-42: 86.

Arellano, Manuel, and Stephen Bond. 1991. Some Tests of Specification for Panel Data: Monte Carlo Evidence and an Application to Employment Equations. The Review of Economic Studies 58(2): 277-297.

Arellano, Manuel, and Olympia Bover. 1995. Another look at the Instrumental Variable Estimation of Error-Components Models. Journal of Econometrics 68(1): 29-51.

Arellano, Cristina, Yan Bai, and Gabriel P. Mihalache. 2020. Deadly Debt Crises: COVID-19 in Emerging Markets. NBER Working paper, (w27275).

Baldacci, Emanuele, Sanjeev Gupta, and Carlos Mulas-Granados. 2009. How Effective is Fiscal Policy Response in Systemic Banking Crises?

Baldwin, Richard, and Beatrice W. di Mauro (eds). 2020. Economics in the Time of COVID-19. A VoxEU.org Book, Centre for Economic Policy Research, London. Accessed 26 March 2020 at: https://voxeu.org/system/files/epublication/COVID-19.pdf

Beck, Thorsten. 2020. Finance in the Times of Coronavirus. In Baldwin, R. and di Mauro, B.W. (eds). Economics in the Time of COVID-19. A VoxEU.org Book, Centre for Economic Policy Research, London. Accessed 26 March 2020 at: https://voxeu.org/system/files/epublication/COVID-19.pdf

Bernardini, Marco, and Lorenzo Forni. 2017. Private and Public Debt: Are Emerging Markets at Risk?

Biron, Bethany, and Yuru Zhu. 2020. Major Fast-Food Chains and Retailers in China are Shutting Their Doors as the Deadly Coronavirus Continues to Spread. Here's a List of Closures. Business Insider. Accessed 31 March 2020 at: https://www.businessinsider.com/coronavirus-fears-mcdonalds-starb ucks-close2020-1

Blanchard, Olivier J. 1984. Current and Anticipated Deficits, Interest Rates and Economic Activity. European Economic Review 25(1): 7-27.

Blundell, Richard, and Stephen Bond. 1998. Initial Conditions and Moment Restrictions in Dynamic Panel Data Models. Journal of Econometrics 87(1): 115-143.

Borensztein, Eduardo, and Ugo Panizza. 2009. The Costs of Sovereign Default. IMF Staff Papers 56(4): 683-741.

Buchheit, Lee C., and Mitu Gulati. 2021. Avoiding a Lost Decade-Sovereign Debt Workouts in the Post-Covid Era. Capital Markets Law Journal 16(1): 45-55.

Cecchetti, Stephen G., and Kermit L. Schoenholtz. 2020. Contagion: Bank Runs and COVID-19. Economics in the Time of COVID-19: 77.

Cochrane, John H. 2020. 12 Coronavirus Monetary Policy. Economics in the Time of COVID- 19: 105.

Comelli, Fabio. 2012. Emerging Market Sovereign Bond Spreads: Estimation and Back-Testing. Emerging Markets Review 13(4): 598-625.

Coulibaly, Brahima. 2012. Monetary Policy in Emerging Market Economies: What Lessons from the Global Financial Crisis? FRB International Finance Discussion Paper 1042: 1-29.

Didier, Tatiana, Constantino Hevia, and Sergio L. Schmukler. 2012. How resilient and countercyclical were emerging economies during the global financial crisis? Journal of International Money and Finance 31(8): 2052-2077.

Dutta, Nabamita, Peter T. Leeson, and Claudia R. Williamson. 2013. the amplification effect: foreign aid's impact on political institutions. Kyklos 66(2): 208-228. 
Edwards, Sebastian. 1986. The Pricing of Bonds and Bank Loans in International Markets: An Empirical Analysis of Developing Countries' Foreign Borrowing. European Economic Review 30(3): 565-589.

Edwards, Sebastian. 1985. The Pricing of Bonds and Bank Loans in International Markets: An Empirical Analysis of Developing Countries' Foreign Borrowing. NBER Working paper, (w1689).

Eichengreen, Barry, and Ricardo Hausmann. 1999. Exchange Rates and Financial Fragility. NBER Working Paper, 7418.

Eichengreen, Barry, and Ashoka Mody. 1998. What Explains Changing Spreads on Emerging-Market Debt: Fundamentals or Market Sentiment?. NBER Working Paper, (w6408).

Eichengreen, Barry. 2020. Coronanomics 101: Which Policy Tools Will Contain the Economic Threat of COVID-19?. World Economic Forum, at: https://www.weforum.org/agenda/2020/03/coronaviruseconomics/ Accessed 12 of March 2020.

Eichler, Stefan. 2014. The political determinants of sovereign bond yield spreads. Journal of International Money and Finance 46: 82-103.

Elmendorf, Douglas W., and N. Gregory Mankiw. 1999. Government Debt. Handbook of Macroeconomics 1: 1615-1669.

Ferrucci, Gianluigi. 2003. Empirical Determinants of Emerging Market Economies Sovereign Bond Spreads.

Flannery, Mark J., and Kristine Watson Hankins. 2013. Estimating Dynamic Panel Models in Corporate Finance. Journal of Corporate Finance 19: 1-19.

Fornaro, Luca, and Martin Wolf. 2020. Covid-19 Coronavirus and Macroeconomic Policy.

Goel, Rajeev K., James W. Saunoris, and Srishti S. Goel. 2021. Supply Chain Performance and Economic Growth: The Impact of COVID-19 Disruptions. Journal of Policy Modeling 43(2): 298-316.

Gormsen, Niels Joachim, and Ralph SJ. Koijen. 2020. Coronavirus: Impact on Stock Prices and Growth Expectations. The Review of Asset Pricing Studies 10(4): 574-597.

Haddad, Valentin, Alan Moreira, and Tyler Muir. 2020. When Selling Becomes Viral: Disruptions in Debt Markets in the COVID-19 Crisis and the Fed's Response, NBER Working Paper, (w27168).

Hartelius, Kristian J., Kenichiro Kashiwase, and Laura E. Kodres. 2008. Emerging Market Spread Compression: Is It Real or is It Liquidity?. IMF Working Papers, 1-36.

Hevia, Constantino, and Andy Neumeyer. 2020. A Conceptual Framework for Analyzing the Economic Impact of Covid-19 and Its Policy Implications. UNDP LAC COVID-19 Policy Documents Series. $1,29$.

Hilscher, Jens, and Yves Nosbusch. 2010. Determinants of Sovereign Risk: macroeconomic fundamentals and the pricing of sovereign debt. Review of Finance 14(2): 235-262.

Hofmann, Boris, Ilhyock Shim, and Hyun Song Shin. 2020. Bond risk premia and the exchange rate. Journal of Money, Credit and Banking 52(S2): 497-520.

Kamin, Steven B., and Karsten Von Kleist. 1999. The Evolution and Determinants of Emerging Markets Credit Spreads in the 1990s.

Kumar, Manmohan S., and Emanuele Baldacci. 2010. Fiscal Deficits, Public debt, and Sovereign Bond Yields. International Monetary Fund.

Lee, Sang H., John Levendis, and Luis Gutierrez. 2012. Telecommunications and Economic Growth: An Empirical Analysis of Sub-Saharan Africa. Applied Economics 44(4): 461-469.

Leijen, Majorie. 2020. European Car Factories Closed Over Concerns of Coronavirus. Railfreight, at: https://www.railfreight.com/business/2020/03/18/european-car-factories-closedover-concerns-coron avirus/?gdpr=accept Accessed 31 March 2020.

Luengnaruemitchai, Pipat, and Susan Schadler. 2007. Do Economists' and Financial Markets' Perspectives on the New Members of the EU Differ? IMF Working Papers, 1-31.

Luo, Shaowen, and Kwok Ping Tsang. 2020. China and world output impact of the hubei lockdown during the coronavirus outbreak. Contemporary Economic Policy 38(4): 583-592.

Maltritz, Dominik, and Alexander Molchanov. 2013. Analyzing determinants of bond yield spreads with bayesian model averaging. Journal of Banking \& Finance 37(12): 5275-5284.

McGuire, Patrick, and Martijn Schrijvers. 2003. Common Factors in Emerging Market Spreads. BIS Quarterly Review, December.

Mihaljek, Dubravko. 2010. The Spread of the Financial Crisis to Central and Eastern Europe: Evidence from the BIS data. In Money Banking and Financial Markets in Central and Eastern Europe,5-31. London: Palgrave Macmillan.

Ocampo, José Antonio. 2009. Latin America and the global financial crisis. Cambridge Journal of Economics 33(4): 703-724. 
Ortmans, Aymeric, and Fabien Tripier. 2021. COVID-Induced Sovereign Risk in the Euro Area: When Did the ECB Stop the Spread?

Paul, De Grauwe, and Yuemei Ji. 2012. Mispricing of Sovereign Risk and Macroeconomic Stability in the Eurozone. Journal of Common Market Studies 50(6): 866-880.

Ribakova, Elina, Benjamin Hilgenstock, and Jonathan Fortun. 2020. Macro Notes-2020 Capital Flows Outlook for Emerging Markets. Institute for International Finance, 8.

Ritchie, Hannah, Esteban Ortiz-Ospina, Diana Beltekian, Edouard Mathieu, Joe Hasell, Bobbie Macdonald, Charlie Giattino, Cameron Appel, Lucas Rodés-Guirao, and Max Roser. 2020. Coronavirus Pandemic (COVID-19). Our World in Data.

Schmitt-Grohé, Stephanie, and Martin Uribe. 2016. Downward Nominal Wage Rigidity, Currency Pegs, and Involuntary Unemployment. Journal of Political Economy 124(5): 1466-1514.

Shi, Jiaoting. 2019. Unemployment and Sovereign Risk. Three essays in macroeconomics, 4.

Sturzenegger, Federico. 2004. Tools for the analysis of debt problems. Journal of Restructuring Finance 1(01): 201-223.

Tebaldi, Edinaldo, Hana Nguyen, and John Zuluaga. 2018. Determinants of emerging markets' financial health: a panel data study of sovereign bond spreads. Research in International Business and Finance 45: 82-93.

Tkalec, Marina, Maruška Vizek, and Miroslav Verbič. 2014. Balance sheet effects and original sinners' risk premiums. Economic Systems 38(4): 597-613.

Tran, Ngan. 2018. Debt threshold for fiscal sustainability assessment in emerging economies. Journal of Policy Modeling 40(2): 375-394.

Uribe, Martin, and Vivian Z. Yue. 2006. Country spreads and emerging countries: who drives whom? Journal of International Economics 69(1): 6-36.

Wong, Perry, Michael C. Lin, and Jessica Jackson. 2020. Best-Performing Cities CHINA 2019. at: https:// milkeninstitute.org/report/best-performing-cities-china-2019 Accessed 31 March 2020

Wren-Lewis, Simon. 2020. The Economic Effects of a Pandemic. at: https://mainlymacro.blogspot.com/ 2020/03/the-economic-effects-of-pandemic.html Accessed 31 March 2020

Publisher's Note Springer Nature remains neutral with regard to jurisdictional claims in published maps and institutional affiliations. 